\title{
Discovery and Molecular Characterization of West Nile Virus NY1999
}

\author{
INGO JORDAN, ${ }^{1}$ THOMAS BRIESE, ${ }^{1}$ and W. IAN LIPKIN ${ }^{1,2}$
}

\section{INTRODUCTION}

$\mathbf{T}$ The field of infectious diseases is enjoying a renaissance in professional and popular media. This interest derives primarily from three concerns: bioterrorism, antibiotic resistance, and emerging infectious diseases. In this article we only discuss the last of these; however, it is important to recognize that the public health infrastructure required to address each is similar. The 1999 outbreak of West Nile virus infections in New York City captured attention beyond its immediate clinical significance because it exposed U.S. vulnerability to exotic infectious agents and demonstrated the importance of investment in public health systems and methods for rapid characterization of and response to novel agents.

West Nile virus is a member of the Japanese encephalitis antigenic complex within the family Flaviviridae, genus Flavivirus $(10,34)$. Other pathogens within this complex include Alfuy, Cacipacore, Koutango, Japanese encephalitis, Kunjin, Murray Valley encephalitis, St. Louis encephalitis, Usutu, and Yaounde viruses (34). West Nile virus is primarily arthropod-borne; mosquitoes are the primary vector for transmission among vertebrate hosts. The name West Nile virus derives from its initial isolation in the West Nile district of Uganda from the blood of a febrile patient in 1937 (83). The first epidemics of West Nile fever were documented in Israel in the early 1950 s $(46,51)$. The largest epidemic reported occurred in South Africa in 1974 after unusual heavy rainfalls and resulted in thousands of hospital admissions (54). Outbreaks of human West Nile virus infection have been reported throughout the Middle East, Sub-Saharan Africa, Europe, Asia (reviewed by Hubálek and Halouzka [37]), and, recently, in the New York City area of North America $(3-5,8,24,48,86)$. There is consensus that West Nile virus outbreaks are increasing in frequency and geographic distribution. Serologic analysis of banked specimens indicates that West Nile virus is likely to have been newly introduced to North America in 1999; however, the extent to which enhanced awareness contributes to increased case ascertainment in other geographic areas is less clear. Factors proposed to contribute to West Nile virus emergence are similar to those described for many other infectious diseases: increased international travel and trade, human incursion into wildlife habitats, and changes in host and vector density and activity $(61,78)$.

The most common clinical presentation of West Nile virus infection is fever associated with headache, myalgias, lymphadenopathy and maculopapular rash $(30,51)$. Meningoencephalitis is less frequent, may be fatal, and typically occurs in elderly or immunosuppressed individuals (85). Rarely, meningoencephalitis occurs in healthy young adults and children (26). The youngest individual with severe meningoencephalitis during the 1999 New York City outbreak was an otherwise healthy 16-year-old. Human infection can also result in myocarditis (2) and pancreatitis (69); however, these complications may be more common in equine and avian hosts. Treatment for West Nile virus infection is supportive; specific antiviral chemotherapy is not available.

Emerging Diseases Laboratory, 'Departments of Microbiology \& Molecular Genetics, ${ }^{2}$ Neurology, Anatomy \& Neurobiology, University of California, Irvine, California. 
In areas in Egypt where West Nile virus is endemic, exposure typically occurs early in childhood and up to $90 \%$ of adults have serologic evidence of previous infection $(19,91)$. The northern Queens serosurvey after the 1999 New York City outbreak indicated an exposure rate of $1.2 \%$ to $4.1 \%$; 62 patients had severe central nervous system (CNS) disease, of which seven cases were fatal (43).

Infection is transmitted chiefly by mosquitoes, although a role for ticks and other hematophagous insects cannot be excluded $(37,40,64,91)$. The ecology of transmission between mosquito vectors and vertebrate hosts is complex. Although many species are competent to carry West Nile virus, feeding preferences differ, as do the geographic distributions of various species. Thus, a mosquito must feed on an infected amplifying host, likely a bird, to serve as an effective vector. The mosquito genus Culex is implicated most commonly worldwide $(37,91)$, and is postulated to have been the major vector in the New York City outbreak $(3,17,25)$. Infected Aedes mosquitoes may also serve as transmission vectors. Birds have sustained high level viremia and are likely to be the most important vertebrate reservoirs for West Nile virus amplification and transmission $(37,55,91,92)$. Bird migration provides a potential basis for viral transport over large distances and has been proposed as an explanation for the seasonal recurrence of West Nile virus infections in temperate zones where winter precludes mosquito activity (77). However, transovarial transmission of virus and overwintering has been demonstrated in mosquitoes. The extent to which these two mechanisms contribute to the epidemiology of West Nile virus infection is unknown.

Infection with West Nile virus is diagnosed by virus isolation, serology, and reverse transcription-polymerase chain reaction (RT-PCR) $(4,7,8,23,28-30,44,54,68,70,71,84)$. Cross-reactivity between members of the Japanese encephalitis antigenic complex can confound serologic analysis; however, specific immunoglobulin M (IgM) capture enzyme-linked immunosorbent assay (ELISA) and neutralization tests have been established (60). Virus is readily cultivated from birds, mosquitoes, and occasionally, horses. Virus load is lower in humans and thus virus isolation may be more difficult. Infectious virus was not isolated from human victims of the 1999 New York City outbreak.

Two genetic lineages are established based on signature motifs in envelope gene sequence (6). Whereas lineage I viruses are associated with outbreaks of acute human disease, lineage II viruses appear to be confined to endemic, enzootic cycles. Flaviviruses infect permissive cells by receptor-mediated endocytosis. Different patterns in neuroinvasiveness and neurovirulence of flaviviruses are typically associated with changes in envelope protein sequence and occasionally with mutations in the nonstructural region $(13,57)$. St. Louis encephalitis and Murray valley encephalitis viruses have been reported to gain entry into the brain by migration along olfactory neurons $(58,59)$. Virus is proposed to infect the olfactory neuroepithelium via blood capillaries during the viremic phase.

\section{WEST NILE VIRUS IN NEW YORK CITY}

In late August 1999, health officials reported an outbreak of encephalitis accompanied by profound muscle weakness and axonal neuropathy in the borough of Queens, New York City $(4,5)$. There was no apparent overall increase in the frequency in New York of encephalitis per se that resulted in detection of the outbreak. Thus, the initial recognition of the syndrome must be credited to the clinical acumen of Dr. Deborah Asnis, an infectious diseases physician at Flushing Hospital Medical Center, Dr. Marcelle Layton, Assistant Commissioner, Communicable Disease Program New York City Department of Health, and their associates.

On September 3, serologic analysis (IgM capture ELISA) for the presence of antibodies to North American arboviruses by the Division of Vector Borne Infectious Diseases of the Centers for Disease Control and Prevention (CDC) in Fort Collins, Colorado, yielded results not inconsistent with infection with St. Louis encephalitis (SLE) virus (4). SLE had not been previously reported in New York City but mosquito vectors competent for transmission of SLE virus were present. Investigation of the outbreak epicenter in northern Queens revealed sites of active mosquito breeding and early victims of the outbreak had histories consistent with mosquito exposure. Thus, on September 3 a mosquito control program was jointly adopted by the State and City of New York (4). Concurrently, wildlife observers independently noted increased mortality of birds, including free-ranging crows and exotic birds housed in the Bronx Zoo. Dr. Tracy McNa- 
mara, a veterinary pathologist at the Wildlife Conservation Society, Bronx, New York, performed histologic analyses of birds and found meningoencephalitis, gross hemorrhage of the brain, splenomegaly, and myocarditis (86). On September 10 she forwarded tissue samples from diseased birds to the United States Department of Agriculture (USDA) National Veterinary Service Laboratory in Ames, Iowa, where virus was isolated and electron micrography was consistent with the presence of either a togavirus or a flavivirus. Thereafter the avian virus was forwarded from the USDA to the CDC Fort Collins for molecular analysis (48).

Incidentally, on September 13-15, the CDC Encephalitis Project (comprised of centers in California, New York and Tennessee) held its annual meeting in Albany, New York. Data from both California and New York over an 18-month survey period indicated that an etiological agent was never identified in $70 \%$ of cases of encephalitis despite culture, serology, and molecular analyses. In this context, our group was invited to discuss methods for identification of unknown pathogens and to consider application to project samples of a new method for amplifying viral nucleic acids, domain-specific differential display (DSDD). DSDD is a hybrid of consensus polymerase chain reaction (PCR) and differential display wherein highly degenerate family-specific primers are used in PCR and resultant products analyzed by polyacrylamide electrophoresis or by chromatography. Efforts to amplify SLE virus sequences by conventional RT-PCR from brains of serologically confirmed human cases of SLE from the New York City outbreak were unsuccessful in several laboratories. Thus, in an effort to circumvent limitations of conventional PCR and to test the utility of the DSDD method we were given brain samples from five people who died during the New York City outbreak.

Several degenerated primer sets were modified from sequences described by Chow et al. (15), Tanaka (90), and Pierre et al. (70) corresponding to the NS3 serine protease/helicase domains and conserved sequence motifs in the NS5 gene and $3^{\prime}$ untranslated region of flaviviruses. Nested primers were located towards the $5^{\prime}$-end of NS5 sequence, spanning conserved amino acid motifs AKGSRAIWXMWLGARXLEFEALGFLNXHW, DDTAGWDT, and QRGSGQVXTY (Fig. 1) (8).

Despite postmortem autolysis to the extent that $28 \mathrm{~S}$ ribosomal RNA was not visible in ethidium bromidestained agarose gels, flavivirus sequences were obtained from 4 of the 5 brain samples on September 22 . Amplification products from two of these subjects (Fig. 1; sequenced amplification products are indicated by boxes) were virtually identical and demonstrated the presence of a virus more similar to Kunjin virus strain MRM61c, an Australasian lineage I West Nile virus, and West Nile virus strain Wengler, a Nigerian lineage II virus, than to St. Louis encephalitis virus (Table 1) (8). Concurrently, our colleagues at the CDC in Fort Collins reported West Nile virus-like sequences in cell lines infected with homogenates from New York birds (4). In concert these findings confirmed that the outbreak in New York City was a zoonosis due to West Nile virus.

In the weeks that followed, our use of the term "Kunjin/West Nile-like" virus for the New York isolate generated considerable controversy (24). Although the Australasian Kunjin virus has historically been considered similar to but different from the African and Eurasian West Nile virus, it has recently been reclassified as a subtype of West Nile virus (34). In retrospect, the similarity of West Nile virus New York 1999

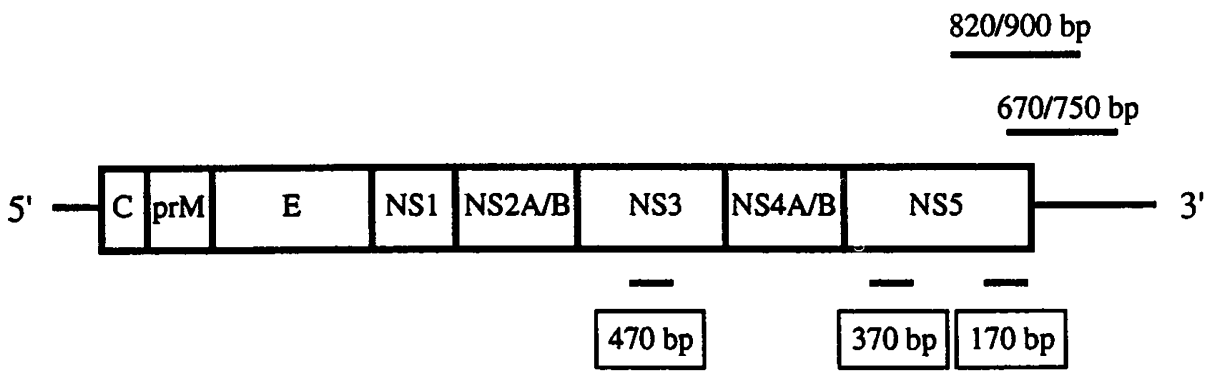

FIG. 1. Positions of primers used for the detection of West Nile virus NY1999. The amplification products indicated by boxes were sequenced directly without subcloning. 
JORDAN ET AL.

Table 1. Sequence Analysis of Amplification Products from the New York 1999 Virus (Patient \#1)

\begin{tabular}{|c|c|c|c|c|c|c|}
\hline \multirow[b]{3}{*}{ Region } & \multicolumn{6}{|c|}{ Percent identity to NY $1999^{\mathrm{a}}$} \\
\hline & \multicolumn{2}{|c|}{ MRM6Ic } & \multicolumn{2}{|c|}{ Wengler } & \multicolumn{2}{|c|}{ St. Louis } \\
\hline & $N T$ & $A A$ & $N T$ & $A A$ & $N T$ & $A A$ \\
\hline NS3 (470 bp) & 88 & 98 & 82 & 94 & NAS & NAS \\
\hline NS5 (370 bp) & 87 & 99 & 80 & 95 & 70 & 76 \\
\hline NS5 (170 bp) & 88 & 100 & 80 & 96 & 80 & 89 \\
\hline
\end{tabular}

aPercent identity of nucleotide (NT) and deduced amino acid (AA) sequence between the three amplified regions of the New York isolate and Kunjin MRM61c, West Nile Wengler, and St. Louis encephalitis MSI.7 viruses; the two fully sequenced West Nile virus genomes and the partial St. Louis encephalitis virus genome available at the time.

NAS, no available sequence.

(NY1999) from human brain to the MRM61c isolate was significant in that it allowed early and accurate recognition of the New York isolate as a lineage I West Nile virus, viruses associated with outbreaks of acute disease.

\section{CHARACTERIZATION OF WEST NILE VIRUS NY1999}

To investigate a possible origin of West Nile virus NY1999, we cloned its genome from postmortem human brain by RT-PCR. RNA integrity was suboptimal; thus, 17 overlapping amplification products were required to assemble a genomic sequence comprising 10,945 nucleotides (41).

The flaviviral envelope (E) protein, encoded by the $E$ gene, is the major target of humoral immune responses, and has a central role in West Nile virus taxonomy. Subtypes of West Nile virus are distinguished by antigenic variations in the E protein $(1,18,27,33,80)$. Two genotypic lineages of West Nile virus are proposed based on specific signature amino acid motifs as well as on the presence or absence of a 12 nucleotide deletion that includes coding sequence for an $\mathrm{N}$-glycosylation site (Asn-Tyr-Ser) at amino acid positions 154-156 (6,80). Lineage I includes West Nile and Kunjin viruses from Europe, the Middle East, and north, central and west Africa, and Australasia. Lineage II includes West Nile virus isolates from west, central, and east Africa, and from Madagascar. Analysis of deduced E protein sequence of West Nile virus NY1999 revealed integrity of the $\mathrm{N}$-glycosylation site and the presence of signature amino acid motifs Ala172, Asn 199, Thr205, Thr208, and Thr210, characteristic of lineage I viruses (41). Phylogenetic analysis of West Nile virus NY1999 E region sequence in relation to other West Nile viruses including Kunjin virus also indicated membership in lineage I (Fig. 2). Assignment of phylogenetic relationship based on short pieces of sequence $(<300 \mathrm{nt})$ from a single genome region may be misleading $(47,80)$. Therefore, we extended our analysis to additional regions for which sequence information was available for other West Nile virus isolates. Analysis of 3' untranslated regions indicated that the West Nile virus NY1999 sequence was most closely related to West Nile virus isolates that had previously been assigned to lineage I based on E gene sequence (Fig. 2). Similarly, phylogenetic analysis of NS3 and NS5 sequences also demonstrated two lineages placing West Nile virus NY1999 with lineage I isolates, not with lineage II isolates (41).

The closest match found was with an isolate obtained in 1998 in Israel (Israel-98). In fact, sequences of West Nile viruses NY1999 and Israel-98 were identical for the 227 nucleotides of E gene sequence available for our analysis (41). Only two mismatches were found in an analysis of a 1278 nucleotide long prM/E sequence, and this high degree of similarity between these two isolates prompted conjecture concerning an Israeli origin of West Nile virus NY1999 (48). It is conceivable that West Nile virus NY1999 arrived in North America through importation of an infected bird or mosquito from Israel; current knowledge suggests that viremia in an infected human travelling to New York from an endemic area may be too low to transfer virus to mosquitoes to initiate an epidemic cycle. Enhanced surveillance in Israel resulted in detection of West Nile virus infection in domestic goslings in Yizre'el and Ramala districts and destruction of 8,000 birds (74). 


\section{WEST NILE VIRUS IN NEW YORK}
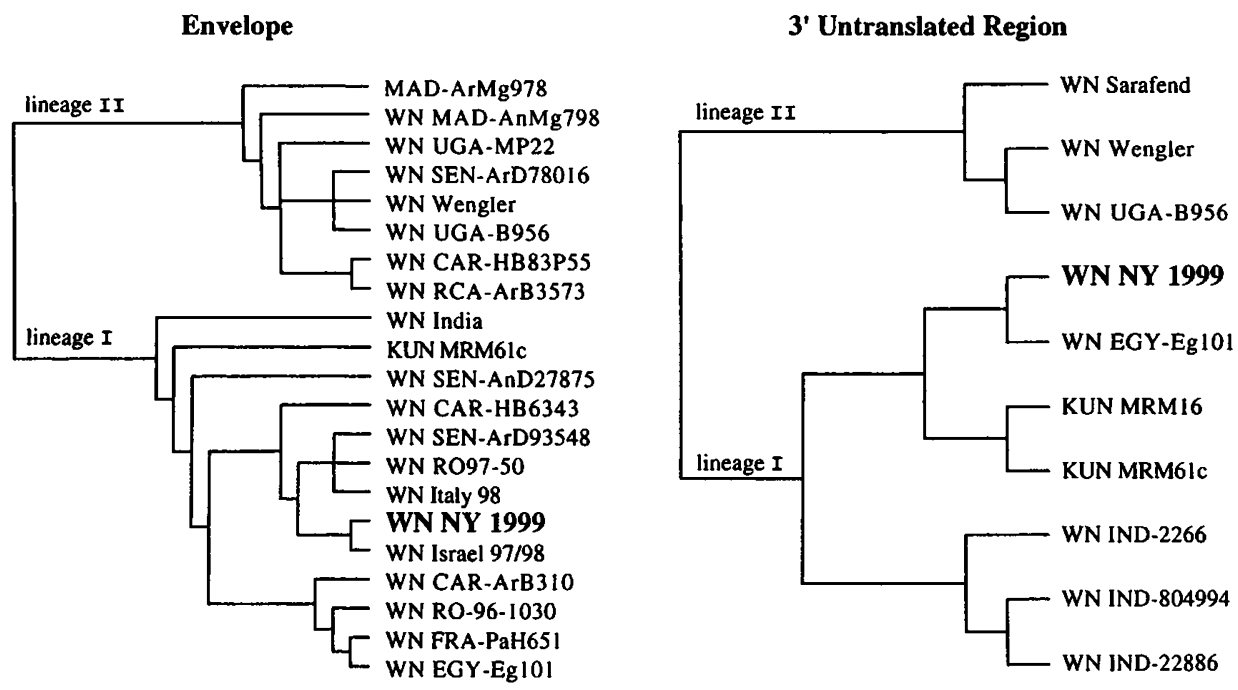

FIG. 2. Phylogenetic analysis of West Nile virus NY1999 envelope and 3' untranslated region.

\section{ESTABLISHMENT OF MOLECULAR ASSAYS FOR DIAGNOSIS OF WEST NILE VIRUS INFECTION}

In early October 1999 in response to requests from several State Departments of Health (New York, Connecticut, Vermont, Florida, California) we posted primer and protocols for RT-PCR detection of West Nile virus NY1999 on ProMED-mail (75). Rapid implementation of this method demonstrated the significance of electronic media in dissemination of diagnostic reagents in outbreak situations. Thereafter, to facilitate high throughput, rapid, and sensitive molecular detection and clinical microbiology of West Nile virus NY1999, we established a real-time 5'-nuclease RT-PCR method (7).

Real-time $5^{\prime}$-nuclease PCR is a method in which the presence of a target sequence is detected through continuous measurement of a fluorescent dye label that is generated by nuclease digestion of a labeled probe oligonucleotide during the course amplification $(35,36,49,50)$. Though nested PCR is similar in sensitivity to real-time PCR, the latter is quantitative over a wide dynamic range, readily adapted to high throughput in a clinical laboratory, and less sensitive to false positive results because assays are performed in a closed system. We established a reverse transcription real-time 5'-nuclease PCR assay for West Nile virus NY1999 using an ABI Prism 7700 Sequence Detector and two primer/fluorescent-probe sets targeting genome regions in the NS3 and NS5 genes (7). The sensitivity of the assays for detection of NS3 or NS5 sequences was determined to be 50-100 molecules using synthetic RNA transcripts corresponding to the respective regions of the West Nile virus NY1999 genome (GenBank Acc. No. AF202541). A linear dynamic range of more than five orders of magnitude was determined using virus tissue culture seed, and specificity for West Nile virus NY1999 was confirmed using NS3 and NS5 sequences of St. Louis encephalitis virus, the other flavivirus of the Japanese encephalitis antigenic complex associated with human disease in North America.

We obtained 18 coded cerebrospinal fluid (CSF) specimens from the New York State Department of Health for blinded analyses: 10 samples from subjects with serologically confirmed West Nile virus NY1999 infection, and 8 samples from subjects with neurologic disease not due to West Nile virus infection. Whereas no West Nile virus sequences were detected in the 8 controls, all 6 samples from serologically confirmed West Nile virus NY 1999 subjects with a fatal outcome were found positive (6 samples from 4 subjects including 3 samples obtained at different time points from 1 subject; 6 positive for NS5, 5 positive for NS3) (7). One sample from one serologically confirmed West Nile virus NY1999 subject with nonfatal outcome was found positive for NS5 sequence; three samples from three serologically confirmed West Nile virus NY1999 subjects with nonfatal outcome were negative by PCR for either gene sequence. The one surviv- 


\section{JORDAN ET AL.}

ing subject with detectable West Nile virus sequences in CSF was a 16-year-old male, the youngest patient with severe disease reported during the outbreak (age of the other cases ranged from 54 to 87 years).

Real-time RT-PCR results can be obtained within hours and may facilitate selection of appropriate therapy, although at this time no specific therapy directed against West Nile virus is available.

\section{IDENTIFICATION OF WEST NILE VIRUS ANTIVIRAL COMPOUNDS}

The finding that West Nile virus had persisted in mosquitoes in New York City over the winter season 1999-2000 (12,17) emphasizes the importance of rapidly identifying antiviral drugs. To initiate antiviral studies we tested a panel of nucleoside analogues for activity against West Nile virus NY1999 in human oligodendrocytes (OL cell line; generated by Y. Iwasaki at the Wistar Institute, Philadelphia, PA, in the 1970s). Two compounds had antiviral activity, pyrazofurin and ribavirin (42). Sensitivity of West Nile virus to pyrazofurin suggests that drugs that impact activity of orotate monophosphate decarboxylase $(9,67)$ in pyrimidine biosynthesis may be useful; however, due to high cytotoxicity, this compound was not tested further. Ribavirin is a guanosine analogue (76) with a broad spectrum of antiviral activities against DNA and RNA viruses $(38,45,81,82)$. Phosphorylated after entry into the host cell it inhibits some viral polymerases $(11,22,93)$; interferes with host cell inosine monophosphate dehydrogenase, resulting in reduction of the intracellular GTP pool (87); reduces translation efficiency of some viral RNAs (31); and at low concentrations can enhance the TH1 antiviral immune response $(63,89)$. Ribavirin has been used for treatment of respiratory syncytial virus infection $(32,88)$, Lassa fever $(52)$, Argentine hemorrhagic fever $(21)$, hemorrhagic fever with renal syndrome caused by Hantaan virus (39), La Crosse encephalitis (56), and (in combination with interferon- $\alpha$ ) hepatitis $C$ virus infection $(20,53,72,79)$.

The effects of ribavirin on West Nile virus NY1999-induced cytopathic effect in the neural cell line, cellular proliferation, and levels of extracellular viral RNA were assessed at various drug concentrations. Levels of ribavirin above $50 \mu \mathrm{M}$ reduced virus-induced cytopathic effect, extracellular viral RNA, and improved proliferation of infected host cells (Fig. 3). Drug-associated inhibition of cellular proliferation was

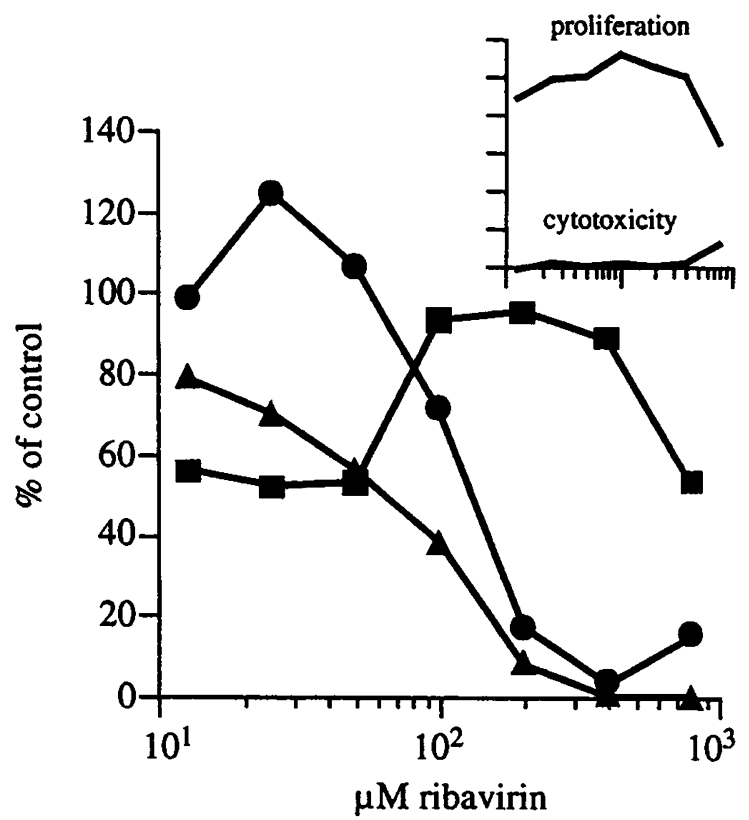

FIG. 3. Effect of ribavirin on West Nile virus replication and pathogenesis in the neural OL cell line. Dosis-dependent effect of ribavirin on virus-induced cytopathic effect (filled squares), infected host cell proliferation (filled circles), and extracellular viral RNA (filled triangles). Parallel controls in uninfected cells included quantitation of druginduced cytotoxicity and effect of ribavirin on cell proliferation (inset). 


\section{WEST NILE VIRUS IN NEW YORK}

observed in both noninfected and infected cells at levels above $400 \mu \mathrm{M}$ of ribavirin. Viral titers were reduced by four orders of magnitude in the presence of $200 \mu \mathrm{M}$ ribavirin (from $10^{7}$ to less than $10^{3}$ plaque forming units per milliliter). Similar experiments were pursued in a nonneural primate cell line, African green monkey kidney (Vero) cells. Higher concentrations of ribavirin were required for inhibition of virusinduced cytopathic effect in Vero than in OL cells.

It is clearly important to identify drugs against West Nile virus infection with better selectivity and therapeutic indices than ribavirin. Furthermore the efficacy of ribavirin in animal models of West Nile virus encephalitis remains to be addressed; a report from 1977 indicates that this drug can decrease mortality due to West Nile virus infection in adult Swiss albino mice (66). There is only limited information available about its efficacy against viral encephalitis in humans but ribavirin has been shown to penetrate into the CNS after oral administration (16). In one case each of La Crosse encephalitis (56) and subacute measles encephalitis (62), treatment with ribavirin was reported to improve prognosis. Ribavirin is highly effective against La Crosse virus in vitro (11); because of weaker antiviral activity against West Nile virus the desirable high therapeutic dosage of ribavirin will likely result in reversible hemolytic anemia that may require transfusion (14).

\section{FUTURE DIRECTIONS}

West Nile virus appears to have established its presence in North America and is likely to extend its global range. At the time this review was submitted for publication in early August 2000 three human patients were reported infected with West Nile virus in North America in 2000 (65). West Nile virus-infected birds were found in a wide area spanning the boroughs of Staten Island and Queens in New York City; as well as several counties in New York, New Jersey, Massachusetts, and Connecticut (65). Positive mosquito pools (Culex spp. and Aedes japonicus) were collected in New York, Connecticut, and Massachusetts $(65,73)$. Insecticide application has resumed in a politically charged atmosphere where pundits debate the relative risks of infection and environmental toxicity. Targeted federal funding has allowed establishment of surveillance networks throughout the eastern United States.

At the height of the 1999 outbreak only a fraction of encephalitis in the greater New York area could be attributed to West Nile virus. National and regional encephalitis incidence data alone would not have revealed the presence of an exotic agent. Recognition of West Nile virus was the result of converging observations from astute physicians and veterinarians in clinical practice who engaged receptive epidemiologists. One lesson therefore is that effective infectious disease surveillance and pathogen discovery require multidisciplinary partnerships in comparative medicine. Another is that it is time to use new technologies and paradigms for investigating the vast majority of encephalitides in which infectious agents have not been detected.

\section{REFERENCES}

1. Adams, S.C., A.K. Broom, L.M. Sammels, A.C. Hartnett, M.J. Howard, R.J. Coelen, J.S. Mackenzie, and R.A. Hall. 1995. Glycosylation and antigenic variation among Kunjin virus isolates. Virology. 206:49-56.

2. Albagali, C., and R. Chaimoff. 1959. A case of West Nile myocarditis. Harefuah. 57:274-275.

3. Anderson, J.F., G.T. Andreadis, C.R. Vossbrinck, S. Tirrell, E.M. Wakem, R.A. French, A.E. Garmendia, and H.J. Van Kruiningen. 1999. Isolation of West Nile virus from mosquitoes, crows, and a Cooper's hawk in Connecticut. Science. 286:2331-2333.

4. Asnis, D., R. Conetta, G. Waldman, A. Teixeira, T. McNamara, A. Fine, M. Layton, J. Miller, D. Cimini, M. Camilo Vargas, A. Inglesby, A. Labowitz, K. Bornschlegel, B. Maldin, E. Samoff, D. Haddow, S. Mullin, J. Gadd, E. Giebelhaus, L. Masuch, A. Sher, M. Foggin, B.J. Mojica, N. Cohen, I. Weisfuse, R. Bhalla, E. Lee, D. Malebrache, G. Sacajiu, A. Sharma, A. Ramon, A. Poshni, H. Stirling, A. Goldberg, J. Hauer, A. Huang, A. Rosenberg, P. Yang-Lewis, H.N. Adel, K. Gaffney, A. Greenberg, B. Smith, M. Sherman, W. Stone, A. Novello, D. White, D. Morse, K. Spitalny, R. Gallo, H. Leib. S. Wong, L.J. Grady, P. Smith, M. Cartter, J. Hadler, W.I. Lipkin, T. Briese, and X.Y. Jia. 1999. Outbreak of West Nile-like viral encephalitis-New York, 1999. MMWR. 48:845-849. 


\section{JORDAN ET AL.}

5. Asnis, D.S., R. Conetta, A. Teixeira, G. Waldman, and B.A. Sampson. 2000. The West Nile virus outbreak of 1999 in New York: The Flushing Hospital experience. Clin. Inf. Dis. 30:413-418.

6. Berthet, F.X., H.G. Zeller, M.T. Drouet, J. Rauzier, J.P. Digoutte, and V. Deubel. 1997. Extensive nucleotide changes and deletions within the envelope glycoprotein gene of Euro-African West Nile viruses. J. Gen. Virol. 78:2293-2297.

7. Briese, T., W.G. Glass, and W.I. Lipkin. 2000. Detection of West Nile virus sequences in cerebrospinal fluid. Lancet 355:1614-1615.

8. Briese, T., X.Y. Jia, C. Huang, L.J. Grady, W.I. Lipkin. 1999. Identification of a Kunjin/West Nile-like flavivirus in brains of patients with New York encephalitis. Lancet. 354:1261-1262.

9. Cadman, E.C., D.E. Dix, and R.E. Handschumacher. 1978. Clinical, biological, and biochemical effect of pyrazofurin. Cancer Res. 38:682-688.

10. Calisher, C.H. 1988. Antigenic classification and taxonomy of flaviviruses (family Flaviviridae) emphasizing a universal system for the taxonomy of viruses causing tick-borne encephalitis. Acta Virol. 32:469-478.

11. Cassidy, L.F., and J.L. Patterson. 1989. Mechanism of La Crosse virus inhibition by ribavirin. Antimicrob. Agents Chemother. 33:2009-2011.

12. CDC. 2000. Update: West Nile virus isolated from mosquitoes-New York, 2000. MMWR. 49:211.

13. Chambers, T.J., M. Halevy, A. Nestorowicz, C.M. Rice, and S. Lustig. 1998. West Nile virus envelope proteins: nucleotide sequence analysis of strains differing in mouse neuroinvasiveness. J. Gen. Virol. 79:2375-2380.

14. Chapman, L.E., G.J. Mertz, C.J. Peters, H.M. Jolson, A.S. Khan, T.G. Ksiazek, F.T. Koster, K.F. Baum, P.E. Rollin, A.T. Pavia, R.C. Holman, J.C. Christenson, P.J. Rubin, R.E. Behrman, L.J. Bell, G.L. Simpson, and R.F. Sadek. 1999. Intravenous ribavirin for hantavirus pulmonary syndrome: Safety and tolerance during 1 year of open-label experience. Ribavirin Study Group. Antivir. Ther. 4:211-219.

15. Chow, V.T.K., C.L.K. Seah, and Y.C. Chan. 1993. Use of NS3 consensus primers for the polymerase chain reaction amplification and sequencing of dengue viruses and other flaviviruses. Arch. Virol. 133:157-170.

16. Connor, E., S. Morrison, J. Lane, J. Oleske, R.L. Sonke, and J. Connor. 1993. Safety, tolerance, and pharmacokinetics of systemic ribavirin in children with human immunodeficiency virus infection. Antimicrob. Agents Chemother. 37:532-539.

17. Cooper, J., J. Miller, B. Bennet, D. White, and P. Smith. 2000. Update: surveillance for West Nile virus in overwintering mosquitoes-New York, 2000. MMWR. 49:178-179.

18. Damle, R.G., L.R. Yeolekar, and B.L. Rao. 1998. Strain analysis and epitope mapping of West Nile virus using monoclonal antibodies. Acta Virol. 42:389-395.

19. Darwish, M., and A.H. Ibrahim. 1975. Prevalence of antibodies to arboviruses in Egypt: results of a serologic survey among 1,113 university students. Am. J. Trop. Med. Hyg. 24:981-985.

20. Davis, G.L., R. Esteban-Mur, V. Rustgi, J. Hoefs, S.C. Gordon, C. Trepo, M.L. Shiffman, S. Zeuzem, A. Craxi, M.H. Ling, and J. Albrecht. 1998. Interferon Alfa-2b alone or in combination with ribavirin for the treatment of relapse of chronic hepatitis C. N. Engl. J. Med. 339:1493-1499.

21. Enria, D.A., A.M. Briggiler, S. Levis, D. Vallejos, J.I. Maiztegui, and P.G. Canonico. 1987. Tolerance and antiviral effect of ribavirin in patients with Argentine hemorrhagic fever. Antiviral Res. 7:353-359.

22. Eriksson, B., E. Helgstrand, N.G. Johansson, A. Larsson, A. Misiorny, J.O. Noren, L. Philipson, K. Stenberg, G. Stening, S. Stridh, and B. Oberg. 1977. Inhibition of influenza virus ribonucleic acid polymerase by ribavirin triphosphate. Antimicrob. Agents Chemother. 11:946-951.

23. Feinstein, S., Y. Akov, B. Lachmi, S. Lehrer, L. Rannon, and D. Katz. 1985. Determination of human IgG and IgM class antibodies to West Nile virus by enzyme linked immunosorbent assay (ELISA). J. Med. Virol. 17:63-72.

24. Fine, A., M. Layton, J. Miller, D. Cimini, M.C. Vargas, A. Inglesby, N. Cohen, I. Weisfuse, A. Ramon, I. Poshni, H. Stirling, T. McNamara, A. Huang, A. Rosenberg, P. Yang-Lewis, H.N. Adel, M. Sherman, G. Terillion, B. Smith, R. Porter. A. Greenberg, K.A. Gaffney, A. Novello, D. White, D. Morse, K. Spitalny, R. Gallo, S. Wong, L. Grady, M. Eidson, B. Wallace, P. Smith, M. Cartter, R. Nelson, J. Hadler, T. Andreadis, J. Blumenstock, J. Degraaf, F. Sorhage, C. Campbell, J. Brook, M. Gerwell, D. Adams, K. Bruder, R. Kent, R. Eisner, N. Halpern, D. 


\section{WEST NILE VIRUS IN NEW YORK}

Roscoe, J. Mackenzie, R. Hall, J. Sherret, J. Smith, M. Parker, K. Steele, and EIS officers CDC. 1999. Update: West Nile virus encephalitis-New York, 1999. MMWR. 48:944-946.

25. Fine, A., M. Layton, J. Miller, D. Cimini, M.C. Vargas, A. Inglesby, A. Labowitz, K. Bornschlegel, B. Maldin, E. Samoff, D. Haddow, S. Mullin, J. Gadd, E. Giebelhaus, L. Mascuch, A. Sher, M. Foggin, B.J. Mojica, N. Cohen, I. Weisfuse, R. Bhalla, E. Lee, D. Malebranche, G. Sacajiu, A. Sharma, M. Eisenberg, A. Ramon, I. Poshni, H. Stirling, A. Goldberg, J. Hauer, A. Huang, A. Rosenberg, P. Yang-Lewis, H.N. Adel, A. Novello, D. White, D. Morse, K. Spitalny, R. Gallo, S. Wong, L. Grady, M. Eidson, B. Wallace, P. Smith, M. Cartter, N. Nelson, J. Hadler, T. Andreadis, J. Degraaf, F. Sorhage, C. Campbell, J. Brook, M. Gerwell, D. Adams, K. Bruder, R. Kent, R. Eisner, N. Halperin, D. Roscoe, E. Bresnitz, and EIS officers CDC. 1999. Update: West Nile-like viral encephalitis-New York, 1999. MMWR. 48:890-892.

26. Flatau, E., D. Kohn, O. Daher, and N. Varsano. 1981. West Nile fever encephalitis. Isr. J. Med. Sci. 17:1057-1059.

27. Gaidamovich, S.Y., and H.J. Sokhey. 1973. Studies on antigenic pecularities of West Nile virus strains isolated in the U.S.S.R. by three serological tests. Acta Virol. 17:343-350.

28. George, S., M. Gourie-Devi, J.A. Rao, S.R. Prasad, and K.M. Pavri. 1984. Isolation of West Nile virus from brains of children who had died of encephalitis. Bull. WHO. 62:879-882.

29. Goldblum, N., V.V. Sterk, and W. Jasinska-Klingberg. 1957. The natural history of West Nile fever. II. Virological findings and the development of homologous and heterologous antibodies in West Nile infection in man. Am. J. Hyg. 66:363-364.

30. Goldblum, N., V.V. Sterk, and B. Paderski, 1954. West Nile fever. The clinical features of the disease and the isolation of West Nile virus from the blood of nine human cases. Am. J. Hyg. 59:89-103.

31. Goswami, B.B., E. Borek, O.K. Sharma, J. Fujitaki, and R.A. Smith. 1979. The broad spectrum antiviral agent ribavirin inhibits capping of mRNA. Biochem. Biophys. Res. Commun. 89:830-836.

32. Hall, C.B., J.T. McBride, E.E. Walsh, D.M. Bell, C.L. Gala, S. Hildreth, L.G. Ten Eyck, and W.J. Hall. 1983. Aerosolized ribavirin treatment of infants with respiratory syncytial viral infection. A randomized double-blind study. N. Engl. J. Med. 308:1443-1447.

33. Hammam, H.M., D.H. Clark, and W.H. Price. 1965. Antigenic variations of West Nile virus in relation to geography. Am. J. Epidemiol. 82:40-55.

34. Heinz, F.X., M.S. Collett, R.H. Purcell, E.A. Gould, C.R. Howard, M. Houghton, R.J.M. Moormann, C.M. Rice, and H.J. Thiel. 2000. Family Flaviviridae Pp 859-878. In M.H. Van Regenmortel, C.M. Fauquet, D.H.L. Bishop, E. Carstens, M.K. Estes, S. Lemon, J. Maniloff, M.A. Mayo, D. McGeoch, C.R. Pringle, and R. Wickner (eds.): Virus taxonomy. 7th Report of the International Committee for the Taxonomy of Viruses. Academic Press, San Diego.

35. Higuchi, R., C. Fockler, G. Dollinger, and R. Watson. 1993. Kinetic PCR analysis: Real-time monitoring of DNA amplification reactions. Biotechnology. 11:1026-1030.

36. Holland, P.M., R.D. Abramson, R. Watson, and D.H. Gelfand. 1991. Detection of specific polymerase chain reaction product by utilizing the $5^{\prime} \pm 3^{\prime}$ exonuclease activity of Thermus aquaticus DNA polymerase. Proc. Natl. Acad. Sci. USA. 88:7276-7280.

37. Hubálek, Z., and J. Halouzka. 1999. West Nile fever-A reemerging mosquito-borne viral disease in Europe. Emerg. Infect. Dis. 5:643-650.

38. Huggins, J.W. 1989. Prospects for treatment of viral hemorrhagic fevers with ribavirin, a broad-spectrum antiviral drug. Rev. Infect. Dis. 11(Suppl 4):S750-761.

39. Huggins, J.W., C.M. Hsiang, T.M. Cosgriff, M.Y. Guang, J.I. Smith, Z.O. Wu, J.W. LeDuc, Z.M. Zheng, J.M. Meegan, Q.N. Wang, D.O. Orland, X.E. Gui, P.H. Gibbs, G.H. Yuan, and T.M. Zhang. 1991. Prospective, doubleblind, concurrent, placebo-controlled clinical trial of intravenous ribavirin therapy of hemorrhagic fever with renal syndrome. J. Infect. Dis. 164:1119-1127.

40. Hurlbut, H.S. 1956. West Nile virus infection in arthropods. Am. J. Trop. Med. Hyg. 5:76-85.

41. Jia, X.Y., T. Briese, I. Jordan, A. Rambaut, H.C. Chi, J.S. Mackenzie, R.A. Hall, J.H. Scherret, and W.I. Lipkin. 1999. Genetic analysis of West Nile New York 1999 encephalitis virus. Lancet. 354:1971-1972.

42. Jordan, I., T. Briese, N. Fischer, J.Y.-N. Lau, and W.I. Lipkin. 2000. Ribavirin inhibits West Nile virus replication and cytopathic effect in neural cells. J. Infect. Dis. 182:1214-1217. 
43. Kaye, K., and A.M. Mojica. 2000. West Nile virus-a Briefing (http://www.ci.nyc.ny.us/html/doh/pdf/chi/chi191.pdf). City Health Information-The New York City Department of Health. 19:1-6.

44. Kerst, A.J., R.S. Lanciotti, K.E. Volpe, B. Davis, N. Komar, N.A. Panella, R. Nasci, C. Mitchell, H.M. Savage, M. Godsey, and J.T. Roehrig. 2000. Detection of West Nile virus in field samples by reverse transcriptase-polymerase chain reaction. 19th Annual Meeting of the American Society for Virology, Fort Collins, CO.

45. Kirsi, J.J., J.A. North, P.A. McKernan, B.K. Murray, P.G. Canonico, J.W. Huggins, P.C. Srivastava, and R.K. Robins. 1983. Broad-spectrum antiviral activity of 2-beta-D-ribofuranosylselenazole-4-carboxamide, a new antiviral agent. Antimicrob. Agents Chemother. 24:353-361.

46. Klingberg, M.A., W. Jasinska-Klingberg, and N. Goldblum. 1959. Certain aspects of the epidemiology and distribution of immunity of West Nile virus in Israel. Proc. 6th Int. Congr. Trop. Med. Malaria 5:132-140.

47. Kuno, G., G.J. Chang, K.R. Tsuchiya, N. Karabatsos, and C.B. Cropp. 1998. Phylogeny of the genus Flavivirus. J. Virol. 72:73-83.

48. Lanciotti, R.S., J.T. Roehrig, V. Deubel, J. Smith, M. Parker, K. Steele, B. Crise, K.E. Volpe, M.B. Crabtree, J.H. Scherret, R.A. Hall, J.S. Mackenzie, C.B. Cropp, B. Panigrahy, E. Ostlund, B. Schmitt, M. Malkinson, C. Banet, J. Weissman, N. Komar, H.M. Savage, W. Stone, T. McNamara, and D.J. Gubler. 1999. Origin of the West Nile virus responsible for an outbreak of encephalitis in the northeastern United States. Science. 286:2333-2337.

49. Lee, L.G., C.R. Connell, and W. Bloch. 1993. Allelic discrimination by nick-translation PCR with fluorogenic probes. Nucleic Acids Res. 21:3761-3766.

50. Livak, K.J., S.J. Flood, J. Marmaro, W. Giusti, and K. Deetz. 1995. Oligonucleotides with fluorescent dyes at opposite ends provide a quenched probe system useful for detecting PCR product and nucleic acid hybridization. PCR Methods Appl. 4:357-362.

51. Marberg, K., N. Goldblum, V.V. Sterk, W. Jasinska-Klingberg, and M.A. Klingberg. 1956. The natural history of West Nile fever. I. Clinical observations during an epidemic in Israel. Am. J. Hyg. 64:259-265.

52. McCormick, J.B., I.J. King, P.A. Webb, C.L. Scribner, R.B. Craven, K.M. Johnson, L.H. Elliott, and R. BelmontWilliams. 1986. Lassa fever. Effective therapy with ribavirin. N. Engl. J. Med. 314:20-26.

53. McHutchison, J.G., S.C. Gordon, E.R. Schiff, M.L. Shiffman, W.M. Lee, V.K. Rustgi, Z.D. Goodman, M.H. Ling, S. Cort, and J.K. Albrecht. 1998. Interferon alfa-2b alone or in combination with ribavirin as initial treatment for chronic hepatitis C. Hepatitis Interventional Therapy Group. N. Engl. J. Med. 339:1485-1492.

54. McIntosh, B.M., P.G. Jupp, I. Dos Santos, and G.M. Meenehan. 1976. Epidemics of West Nile and Sindbis viruses in South Africe with Culex (Culex) univittatus Theobald as vector. S. Afr. J. Sci. 72:295-300.

55. McIntosh, B.M., G.M. McGillivray, D.B. Dickinson, and J.J. Taljaard. 1968. Ecological studies on Sindbis and West Nile viruses in South Africa. IV. Infection in a wild avian population. S. Afr. J. Med. Sci. 33:105-112.

56. McJunkin, J.E., R. Khan, E.C. de los Reyes, D.L. Parsons, L.L. Minnich, R.G. Ashley, and T.F. Tsai. 1997. Treatment of severe La Crosse encephalitis with intravenous ribavirin following diagnosis by brain biopsy. Pediatrics. 99:261-267.

57. McMinn, P.C. 1997. The molecular basis of virulence of the encephalitogenic flaviviruses. J. Gen. Virol. 78:2711-2722.

58. McMinn, P.C., L. Dalgarno, and R.C. Weir. 1996. A comparison of the spread of Murray Valley encephalitis viruses of high or low neuroinvasiveness in the tissues of Swiss mice after peripheral inoculation. Virology. 220:414-423.

59. Monath, T.P., C.B. Cropp, and A.K. Harrison. 1983. Mode of entry of a neurotropic arbovirus into the central nervous system. Reinvestigation of an old controversy. Lab. Invest. 48:399-410.

60. Monath, T.P., R.R. Nystrom, R.E. Bailey, C.H. Calisher, and D.J. Muth. 1984. Immunoglobulin M antibody capture enzyme-linked immunosorbent assay for diagnosis of St. Louis encephalitis. J. Clin. Microbiol. 20:784-790.

61. Morse, S.S. 1995. Factors in the emergence of infectious diseases. Emerg. Inf. Dis. 1:7-15.

62. Mustafa, M.M., S.D. Weitman, N.J. Winick, W.J. Bellini, C.F. Timmons, and J.D. Siegel. 1993. Subacute measles encephalitis in the young immunocompromised host: report of two cases diagnosed by polymerase chain reaction and treated with ribavirin and review of the literature. Clin. Infect. Dis. 16:654-660. 


\section{WEST NILE VIRUS IN NEW YORK}

63. Ning, Q., D. Brown, J. Parodo, M. Cattral, R. Gorczynski, E. Cole, L. Fung, J.W. Ding, M.F. Liu, O. Rotstein, M.J. Phillips, and G. Levy. 1998. Ribavirin inhibits viral-induced macrophage production of TNF, IL-1, the procoagulant fgl2 prothrombinase and preserves Th1 cytokine production but inhibits Th2 cytokine response. J. Immunol. 160:3487-3493.

64. Nir, Y., and R. Goldwasser. 1972. Arbovirus activity in Israel. Isr. J. Med. Sci. 8:1695-1701.

65. Novello, A., D. White, L. Kramer, C. Trimarchi, M. Eidson, D. Morse, B. Wallace, P. Smith, W. Stone, V. Kulasekera, L. Mill, A. Fine, J. Miller, M. Layton, W. Crans, F. Sorhage, E. Bresnitz, R. French, A. Garmendia, T. Andreadis, J. Anderson, R. Nelson, D. Mayo, M. Cartter, J. Hadler, B. Werner, R. Timperi, A. DeMaria, P. Kelley, M. Bunning, and EIS officers CDC. 2000. Update: West Nile virus activity-northeastern United States, January-August 7, 2000. MMWR. 49:714-715.

66. Odelola, H.A. 1977. Antiviral activity of virazole on replication of viruses isolated in Nigeria. Current Chemotherapy. Proc. 10th Intl. Congr. Chemother. Zürich, Switzerland pp 334-335.

67. Olah, E., M.S. Liu, D.Y. Tzeng, and G. Weber. 1980. Phase and cell cycle specificity of pyrazofurin action. Cancer Res. 40:2869-2875.

68. Panthier, R., C. Hannoun, D. Beytout, and J. Mouchet. 1968. Epidemiologie du virus West Nile. Etude d'un foyer en Camargue. III. Les maladies humaines. Ann. Inst. Pasteur. 115:435-445.

69. Perelman, A., and J. Stern. 1974. Acute pancreatitis in West Nile fever. Am. J. Trop. Med. Hyg. 23:1150-1152.

70. Pierre, V., M.T. Drouet, and V. Deubel. 1994. Identification of mosquito-borne flavivirus sequences using universal primers and reverse transcription/polymerase chain reaction. Res. Virol. 145:93-104.

71. Porter, K.R., P.L. Summers, D. Dubois, B. Puri, W. Nelson, E. Henchal, J.J. Oprandy, and C.G. Hayes. 1993. Detection of West Nile virus by the polymerase chain reaction and analysis of nucleotide sequence variation. Am. $J$. Trop. Med. Hyg. 48:440-446.

72. Poynard, T., P. Marcellin, S.S. Lee, C. Niederau, G.S. Minuk, G. Ideo, V. Bain, J. Heathcote, S. Zeuzem, C. Trepo, and J. Albrecht. 1998. Randomised trial of interferon alpha2b plus ribavirin for 48 weeks or for 24 weeks versus interferon alpha2b plus placebo for 48 weeks for treatment of chronic infection with hepatitis $\mathrm{C}$ virus. International Hepatitis Interventional Therapy Group (IHIT). Lancet. 352:1426-1432.

73. ProMED-mail. 21 July 1999. West Nile virus surveillance-USA (03) 2000 \#170.

74. ProMED-mail. 08 Dec. 1999. West Nile virus, geese-Israel (02) 99 \#298.

75. ProMED-mail. 13 Oct. 1999. West Nile-like virus: PCR promers \& protocols 99 \#254.

76. Prusiner, P., and M. Sundaralingam. 1973. A new class of synthetic nucleoside analogues with broad-spectrum antiviral properties. Nat. New Biol. 244:116-118.

77. Rappole, J.H., S.R. Derrickson, and Z. Hubalek. 2000. Migratory Birds and Spread of West Nile Virus in the Western Hemisphere. Emerg. Infect. Dis. 6:319-328.

78. Reeves, W.C., J.L. Hardy, W.K. Reisen, and M.M. Milby. 1994. Potential effect of global warming on mosquitoborne arboviruses. J. Med. Entomol. 310:323-332.

79. Reichard, O., G. Norkrans, A. Fryden, J.H. Braconier, A. Sonnerborg, and O. Weiland. 1998. Randomised, double-blind, placebo-controlled trial of interferon alpha- $2 b$ with and without ribavirin for chronic hepatitis $\mathrm{C}$. The Swedish Study Group. Lancet. 351:83-87.

80. Savage, H.M., C. Ceianu, G. Nicolescu, N. Karabatsos, R. Lanciotti, A. Vladimirescu, L. Laiv, A. Ungureanu, C. Romanca, and T.F. Tsai. 1999. Entomologic and avian investigations of an epidemic of West Nile fever in Romania in 1996, with serologic and molecular characterization of a virus isolate from mosquitoes. Am. J. Trop. Med. Hyg. 61:600-611.

81. Sidwell, R.W., J.H. Huffman, G.P. Khare, L.B. Allen, J.T. Witkowski, and R.K. Robins. 1972. Broad-spectrum antiviral activity of Virazole: 1-beta-D-ribofuranosyl-1,2,4-triazole-3-carboxamide. Science. 177:705-706.

82. Sidwell, R.W., R.K. Robins, and I.W. Hillyard. 1979. Ribavirin: An antiviral agent. Pharmacol. Ther. 6:123-146.

83. Smithburn, K.C., T.P. Hughes, A.W. Burke, and J.H. Paul. 1940. A neurotropic virus isolated from the blood of a native of Uganda. Am. J. Trop. Med. Hyg. 20:471-492. 


\section{JORDAN ET AL.}

84. Southam, C.M., and A.E. Moore. 1954. Induced virus infections in man by the Egypt isolates of West Nile virus. Am. J. Trop. Med. Hyg. 3:19.

85. Spigland, I., W. Jasinska-Klingberg, E. Hofsbi, and N. Goldblum. 1958. Clinical and laboratory observations in an outbreak of West Nile fever in Israel in 1957. Harefuah. 54:280-281.

86. Steele, K.E., M.J. Linn, R.J. Schoepp, N. Komar, T.W. Geisbert. R.M. Manduca, P.P. Calle, B.L. Raphael, T.L. Clippinger, T. Larsen, J. Smith, R.S. Lanciotti, N.A. Panella, and T.S. McNamara. 2000. Pathology of fatal West Nile virus infection in native and exotic birds during the 1999 outbreak in New York City, New York. Vet. Pathol. 37:208-224.

87. Streeter, D.G., J.T. Witkowski, G.P. Khare, R.W. Sidwell, R.J. Bauer, R.K. Robins, and L.N. Simon. 1973. Mechanism of action of 1- $\beta$-D-ribofuranosyl-1,2,4-triazole-3-carboxamide (Virazole), a new broad-spectrum antiviral agent. Proc. Natl. Acad. Sci. USA. 70:1174-1178.

88. Taber, L.H., V. Knight, B.E. Gilbert, H.W. McClung, S.Z. Wilson, H.J. Norton, J.M. Thurson, W.H. Gordon, R.L. Atmar, and W.R. Schlaudt. 1983. Ribavirin aerosol treatment of bronchiolitis associated with respiratory syncytial virus infection in infants. Pediatrics. 72:613-618.

89. Tam, R.C., B. Pai, J. Bard, C. Lim, D.R. Averett, U.T. Phan, and T. Milovanovic. 1999. Ribavirin polarizes human $\mathrm{T}$ cell responses towards a type 1 cytokine profile. J. Hepatol. 30:376-382.

90. Tanaka, M. 1993. Rapid identification of flavivirus using the polymerase chain reaction. J. Virol. Methods. 41:311-322.

91. Taylor, R.M., T.H. Work, H.S. Hurlbut, and F. Rizk. 1956. A study of the ecology of West Nile virus in Egypt. Am. J. Trop. Med. Hyg. 5:579-620.

92. Work, T.H., H.S. Hurlbut, and R.M. Taylor. 1995. Indigenous wild birds of the Nile Delta as potential West Nile virus circulating reservoirs. Am. J. Trop. Med. Hyg. 4:872-878.

93. Wray, S.K., B.E. Gilbert, and V. Knight. 1985. Effect of ribavirin triphosphate on primer generation and elongation during influenza virus transcription in vitro. Antiviral Res. 5:39-48.

Address reprint requests to:

W. Ian Lipkin

Emerging Disease Laboratory 3101 Gillespie Neuroscience Building

University of California

Irvine, CA $92697-4292$

E-mail: ilipkin@uci.edu 
This article has been cited by:

1. Sandro Cinti. 2009. Chikungunya Fever. Infectious Diseases in Clinical Practice 17:1, 6-11. [CrossRef]

2. Anh N Woodmansee, Pei-Yong Shi. 2003. Recent developments in West Nile virus vaccine and antiviral therapy. Expert Opinion on Therapeutic Patents 13:8, 1113-1125. [CrossRef]

3. Micheline McCarthy. 2001. St. Louis encephalitis and West nile virus encephalitis. Current Treatment Options in Neurology 3:5, 433-438. [CrossRef]

4. Carl J. MitchellArthropod Vector and Vertebrate Host Associations of West Nile Virus 269-279. [CrossRef]

5. Jo Ellen Brunner, Bert L. SemlerPositive-Strand RNA Virus Replication in Vertebrate Hosts . [CrossRef] 